\title{
Screening of Mineral Elements in Cistus ladanifer and Cistus libanotis Essential Oils and their Leaves
}

\author{
H. ZIDANE ${ }^{1 *}$, F. AOUNITI ${ }^{1}$,A. TAHANI ${ }^{1}$, M.L. FAUCONNIER ${ }^{2}$ and A. ELBACHIRI ${ }^{1}$ \\ 'Laboratory of Physical Chemistry of the Natural Resources and Environment, \\ University Mohammed Premier, BP 717, 60000 Oujda, Morocco. \\ ${ }^{2}$ Units of General and Organic Chemistry University of Liege Gembloux Agro-Bio Tech, Belgium. \\ ${ }^{*}$ Corresponding author E-mail: zidane-hanane@live.fr \\ http://dx.doi.org/10.13005/ojc/290407
}

(Received: August 28, 2013; Accepted: October 29, 2013)

\begin{abstract}
The aim of this study was to determine the levels of mineral compounds in Cistus ladanifer and Cistus libanotis growing in Eastern Morocco from two different regions Jerada (arid climate) and Tafoughalt (humid climate). A total of fifteen elements (Cd, Co, $\mathrm{Cr}, \mathrm{Cu}, \mathrm{Hg}, \mathrm{Na}, \mathrm{Ni}, \mathrm{P}, \mathrm{Pb}, \mathrm{Zn}, \mathrm{Al}$, $\mathrm{Ca}, \mathrm{Fe}, \mathrm{K}$ and $\mathrm{Mg}$ ) has been measured by inductive coupled plasma atomic emission spectrometry. Their concentrations have been found to vary in leaves and their essential oils. From the results of the study, P, Al, Ca, Fe, $\mathrm{K}$ and $\mathrm{Mg}$ are highest in all the samples analysed. $\mathrm{Cr}$ and $\mathrm{Pb}$ were not detected in essential oil of Cistus libanotis from Jerada and Tafoughalt, respectively. These plants were found to contain appreciable amounts of the elements $\mathrm{K}, \mathrm{Ca}, \mathrm{Fe}, \mathrm{Mg}, \mathrm{P}, \mathrm{Al}, \mathrm{Ni}, \mathrm{Li}, \mathrm{Zn}$ and $\mathrm{Cu}$ Witch are important in many biological mechanisms. This study also provides a comprehensive survey of the concentration of elements in plants due to their wide utilisation as herbal fusion or decoction in Eastern Morocco.
\end{abstract}

Key words: Trace element, Essential oil, Cistus ladanifer, Cistus libanotis, ICP-AES.

\section{INTRODUCTION}

Cistus ladanifer and Cistus libanotis are two species of genus Cistus (Cistaceae) widely present in the Mediterranean area. Cistus ladanifer is used for treatment of various skin diseases, as anti-diarrhoeal and as anti-inflammatory agents ${ }^{1}$. In Eastern Morocco, Cistus ladanifer and Cistus libanotis are used against diarrhea by simple decoction of their leaves. The decoction extract of Cistus ladanifer from Morocco was evaluated for their anti-diarrheal effect $^{2}$. Furthermore, extract from Cistus ladanifer was characterized to possec biological effect such as antihypertensive ${ }^{3}$, antimicrobial ${ }^{4}$, antioxidant ${ }^{5}$, antifungal ${ }^{6}$, antiaggregant ${ }^{7}$, and relaxant effect ${ }^{8}$.

Eating patents of people all over the worth have recently undergone marked changes, due to the globalization of markets along with innovation in food technology 9 . 
Many elements in trace element play an important role in metabolic processes and are essential for general well being of humans. Some of the important elements are $\mathrm{Ca}, \mathrm{K}, \mathrm{Na}, \mathrm{Mg}, \mathrm{Fe}, \mathrm{Mn}$, $\mathrm{P}, \mathrm{Zn}, \mathrm{Cr}, \mathrm{Cu}, \mathrm{F}, \mathrm{Se}, \mathrm{Mo}$, and $\mathrm{I}^{10}$. Trace elements play a very important role in the formation of the active chemical constituents present in medicinal plants and they are, therefore, responsible for their medicinal as well as toxic properties ${ }^{11}$. It has been reported that the absorption of toxic metals through skin is very insignificant and can cause deleterious effects on our body ${ }^{12-13}$.

Major minerals (calcium, phosphorus, magnesium, sulphur, potassium, chloride and sodium) can be defined as amounts greater than $100 \mathrm{mg}$ per day and they represent $1 \%$ or less of bodyweight. Whereas trace minerals are essential in much smaller amounts, less than 100 mg per day, and make up less than $0.01 \%$ of body weight ${ }^{14}$.

The heavy metals contamination in traditional medicines may occur due to polluted environment in which the medicinal plants grow ${ }^{15}$, the polluted conditions in which the plants are dried and processed, the storage conditions and/ or manufacture of the products in the final dosage form ${ }^{16}$

The chemical constituents in plants, including metal ions, are partially responsible for their medicinal and nutritional properties as well as the toxic ones. As trace elements, they play an important role in the plant metabolism and biosynthesis as cofactors for enzymes ${ }^{17}$. In other approach, the use of plant is crucial on phytostabilization for treatment of environmental problems such as adsorption or accumulation of pollutants in plant ${ }^{18}$.

In general, essential oils are used widely in perfurmy and cosmetics and in the food industry. They are demonstrated to have many biological properties and effects such as antiseptic, appetitestimulating, analgesic and other mores. The wide use of essential oils requires strict control ${ }^{19}$.

Abundant research work has been carried out on the organic constituents of the medicinal plants while little attention has been paid on the role of inorganic elements in the medicinal use of Cistus ladanifer and Cistus libanotis growing in Eastern Morocco.

The objective of this study was to quantify the content of various elements that might be responsible for some properties. Investigated elements were chosen ( $\mathrm{Cd}, \mathrm{Co}, \mathrm{Cr}, \mathrm{Cu}, \mathrm{Hg}, \mathrm{Na}, \mathrm{Ni}$, $\mathrm{P}, \mathrm{Pb}, \mathrm{Zn}, \mathrm{Al}, \mathrm{Ca}, \mathrm{Fe}, \mathrm{K}$ and $\mathrm{Mg}$ ).

\section{MATERIALS AND METHODS}

\section{Collection of plant material}

Cistus ladanifer was collected from Eastern Morocco (Tafoughalt). Cistus libanotis was collected also from Eastern Morocco (Tafoughalt and Jerrada). The voucher specimens were identified by Dr. Haloui of department of biology (University Mohamed Premier Oujda). Collected plants were dried in laboratory under normal air at room temperature.

\section{Isolation of essential oil}

The essential oil from leaves of Cistus ladanifer and Cistus libanotis was obtained by hydrodistillation in a Clevenger-type apparatus during 5 and $4 \mathrm{~h}$ respectively. Both oils were dried under anhydrous sulphate and stored at $4{ }^{\circ} \mathrm{C}$ until used. Apparatus was carefully washed with nitric acid and bi-distilled water.

\section{Apparatus}

The samples were powdered and transferred into plastic bags. For acid digestion, Samples $(0.1500$ g) were ashed with $2 \mathrm{ml} \mathrm{HNO}_{3}$ acid (70\%) in a Teflon beaker. The samples were incinerated at 110 ${ }^{\circ} \mathrm{C}$ and $0.5 \mathrm{ml}$ of hydrofluoric acid (HF) was added and the covered beaker placed on a sand bath. The resulted mixture was heated until a clear solution was obtained. After removing the cover, the mixture was evaporated until dry. Then, $2 \mathrm{ml}$ of $\mathrm{HCl}$ acid was added. The residue was extracted by $25 \mathrm{ml} 2 \mathrm{M} \mathrm{HCl}$. Essential oils were diluted with $\mathrm{HNO}_{3}(1: 15)(\mathrm{v} / \mathrm{v})$. Concentrations were carried out using ICP-AES and application of the following operation parameters: ICPAES (ULTIMA 2, Jobin-Yvon); frequency: 45-65 HZ; power: 1150 watts; plasma gas flow rate (Ar): $12 \mathrm{~L} / \mathrm{min}$; pump speed: $20 \mathrm{tr} / \mathrm{mn}$. The samples were injected continuously through a pump that turns until the analysis was late (4 $\mathrm{mn}$ per element). 


\section{Statistical data}

Principal component analysis (PCA), hierarchical cluster analysis and correlation coefficients ( $r$ ) were determined by the pearson correlation matrix method. All the tests were carried out using SPSS 11.5 for windows.

\section{RESULT AND DISCUSSION}

The fifteen elements ( $\mathrm{Cd}, \mathrm{Co}, \mathrm{Cr}, \mathrm{Cu}, \mathrm{Hg}$, $\mathrm{Na}, \mathrm{Ni}, \mathrm{P}, \mathrm{Pb}, \mathrm{Zn}, \mathrm{Al}, \mathrm{Ca}, \mathrm{Fe}, \mathrm{K}$ and $\mathrm{Mg}$ ) contents of Cistus ladanifer and Cistus libanotis of leaves and essential oils from two regions from Eastern Morocco were determined by inductive coupled plasma atomic emission spectrometry (ICP-AES). The concentrations are listed in table $1 . \mathrm{Hg}$ is the only element present almost equal concentration in all plants leaves and essential oils and their soils. Calcium is found to be higher on all samples tested. Brody ${ }^{21}$ reported that calcium is the major component of bone and assists in teeth development.

For Cistus ladanifer, it can be seen that $\mathrm{K}, \mathrm{Ca}, \mathrm{Mg}, \mathrm{Al}$ and $\mathrm{P}$ are present at higher concentrations in the leaves and essential oil with an exception content of $\mathrm{P}(0.01 \mathrm{ppm})$ in Cistus ladanifer essential oil. The trace element content of leaves and essential oil is influenced by the trace element content in the soils on which they were grown.

For Cistus libanotis from the same region (Tafoughalt) was characterized by abundance of $\mathrm{K}$, $\mathrm{Mg}, \mathrm{Ca}$, and $\mathrm{P}$ in the leaves. The level of $\mathrm{Al}, \mathrm{Fe}$ and $\mathrm{Mg}$ were found to be higher in essential oil than leaves.

Several factors cited by Özcan $\mathrm{M}^{14}$ can affect the concentration of trace element in plants such as genetic factors, geographical variations and analytical procedures.

Table 1 shows also wide variation in the elemental concentration of the different soils studied. Analysis of the present data reveals that the elements $\mathrm{Al}, \mathrm{Ca}, \mathrm{Fe}, \mathrm{K}, \mathrm{Mg}$ and $\mathrm{P}$ are found in major concentrations in these soils. $\mathrm{Ca}$ is observed in highest concentration in soil from Tafoughalt and Fe is highest in soil from Jerada.

Table 1: Concentration of elements presents in soil and in two medicinal plants (Cistus ladanifer and Cistus libanotis)

\begin{tabular}{|c|c|c|c|c|c|c|c|c|}
\hline \multirow{4}{*}{$\begin{array}{l}\text { Samples } \\
\text { Elements }\end{array}$} & \multicolumn{7}{|c|}{ Region } & \\
\hline & \multicolumn{4}{|c|}{ Tafoughalt } & \multicolumn{4}{|c|}{ Jerada } \\
\hline & \multicolumn{2}{|c|}{ Cistus ladanifer } & \multicolumn{2}{|c|}{ Cistus libanotis } & \multirow[t]{2}{*}{ Soil } & \multicolumn{2}{|c|}{ Cistus libanotis } & \multirow[t]{2}{*}{ Soil } \\
\hline & $\begin{array}{c}\text { Essential } \\
\text { oil }\end{array}$ & Leaves & $\begin{array}{c}\text { Essential } \\
\text { oil }\end{array}$ & Leaves & & $\begin{array}{c}\text { Essentia } \\
\text { oil }\end{array}$ & I Leaves & \\
\hline $\mathrm{Cd}$ & 0.01 & 1.57 & 0.01 & 1.70 & 2.89 & 0.01 & 1.38 & 3.48 \\
\hline Co & 0.01 & 1.99 & 0.01 & 1.34 & 7.96 & 0.01 & 1.48 & 11.52 \\
\hline $\mathrm{Cr}$ & 0.01 & 2.30 & 0.01 & 1.22 & 24.11 & 0.00 & 2.33 & 40.44 \\
\hline $\mathrm{Cu}$ & 0.01 & 13.72 & 0.02 & 9.48 & 9.16 & 0.01 & 7.19 & 25.71 \\
\hline $\mathrm{Hg}$ & 0.01 & 1.05 & 0.01 & 1.22 & 2.41 & 0.01 & 1.06 & 2.68 \\
\hline $\mathrm{Na}$ & 1.60 & 673.72 & 1.71 & 642.30 & 313.65 & 1.97 & 7.93 & 407.31 \\
\hline $\mathrm{Ni}$ & 0.08 & 6.91 & 0.08 & 5.22 & 7.96 & 0.07 & 4.55 & 14.73 \\
\hline $\mathrm{P}$ & 0.01 & 1899.63 & 0.48 & 1523.98 & 139.35 & 0.06 & 1136.50 & 337.42 \\
\hline $\mathrm{Pb}$ & 0.01 & 39.29 & 0.00 & 60.88 & 10.37 & 0.02 & 34.90 & 23.83 \\
\hline $\mathrm{Zn}$ & 0.05 & 63.25 & 0.04 & 44.48 & 24.11 & 0.06 & 38.12 & 63.16 \\
\hline $\mathrm{Al}$ & 1200 & 1000 & 1000 & 700 & 10600 & 800 & 900 & 15100 \\
\hline $\mathrm{Ca}$ & 13000 & 13800 & 11900 & 14700 & 3600 & 17700 & 14600 & 79300 \\
\hline $\mathrm{Fe}$ & 900 & 600 & 1200 & 200 & 11800 & 1200 & 500 & 2840 \\
\hline $\mathrm{K}$ & 2400 & 26800 & 2500 & 16900 & 4900 & 1100 & 10600 & 13600 \\
\hline $\mathrm{Mg}$ & 13900 & 2500 & 4400 & 1700 & 2600 & 5500 & 2000 & 6400 \\
\hline
\end{tabular}


Table 2: Correlation matrix of elements presents in two medicinal plants (Cistus ladanifer and Cistus libanotis)

\begin{tabular}{|c|c|c|c|c|c|c|c|c|c|c|c|c|c|c|c|}
\hline & Cd & Co & $\mathrm{Cr}$ & $\mathrm{Cu}$ & $\mathrm{Hg}$ & $\mathrm{Na}$ & $\mathbf{N i}$ & $\mathbf{P}$ & $\mathrm{Pb}$ & $\mathrm{Zn}$ & Al & $\mathrm{Ca}$ & $\mathrm{Fe}$ & K & $\mathrm{Mg}$ \\
\hline $\mathrm{Cd}$ & 1 & & & & & & & & & & & & & & \\
\hline Co & 0,92 & 1 & & & & & & & & & & & & & \\
\hline $\mathrm{Cr}$ & 0,86 & 0,99 & 1 & & & & & & & & & & & & \\
\hline $\mathrm{Cu}$ & 0,89 & 0,83 & 0,79 & 1 & & & & & & & & & & & \\
\hline $\mathrm{Hg}$ & 0,99 & 0,93 & 0,88 & 0,86 & 1 & & & & & & & & & & \\
\hline $\mathrm{Na}$ & 0,60 & 0,36 & 0,27 & 0,66 & 0,54 & 1 & & & & & & & & & \\
\hline $\mathrm{Ni}$ & 0,96 & 0,92 & 0,88 & 0,98 & 0,94 & 0,61 & 1 & & & & & & & & \\
\hline$P$ & 0,24 & $-0,12$ & $-0,23$ & 0,37 & 0,17 & 0,73 & 0,27 & 1 & & & & & & & \\
\hline $\mathrm{Pb}$ & 0,44 & 0,08 & $-0,01$ & 0,49 & 0,38 & 0,76 & 0,43 & 0,90 & 1 & & & & & & \\
\hline $\mathrm{Zn}$ & 0,77 & 0,55 & 0,47 & 0,89 & 0,71 & 0,80 & 0,84 & 0,74 & 0,78 & 1 & & & & & \\
\hline $\mathrm{Al}$ & 0,83 & 0,98 & 0,99 & 0,74 & 0,86 & 0,22 & 0,83 & $-0,29$ & $-0,09$ & 0,39 & 1 & & & & \\
\hline $\mathrm{Ca}$ & 0,54 & 0,69 & 0,75 & 0,77 & 0,52 & 0,19 & 0,71 & $-0,11$ & 0,08 & 0,49 & 0,69 & 1 & & & \\
\hline $\mathrm{Fe}$ & 0,78 & 0,95 & 0,98 & 0,79 & 0,79 & 0,21 & 0,84 & $-0,28$ & $-0,06$ & 0,44 & 0,97 & 0,85 & 1 & & \\
\hline $\mathrm{K}$ & 0,46 & 0,18 & 0,09 & 0,64 & 0,37 & 0,86 & 0,54 & 0,92 & 0,82 & 0,89 & 0,01 & 0,19 & 0,05 & 1 & \\
\hline $\mathrm{Mg}$ & $-0,38$ & $-0,11$ & $-0,02$ & $-0,26$ & $-0,36$ & $-0,45$ & $-0,29$ & $-0,57$ & $-0,59$ & $-0,47$ & 0,02 & 0,17 & 0,07 & $-0,46$ & 1 \\
\hline
\end{tabular}

$\mathrm{Cd}, \mathrm{Co}, \mathrm{Cr}, \mathrm{Cu}, \mathrm{Na}, \mathrm{Ni}, \mathrm{P}, \mathrm{Pb}$, and $\mathrm{Zn}$ are present in all the analyzed samples, with an exception content of $\mathrm{Cr}(0.00 \mathrm{ppm})$ and $\mathrm{Pb}(0.00$ ppm) in Cistus libanotis essential oil from Jerada and Tafoughalt, respectively. Among all these elements are found highest in leaves and soils whether they are lowest in essential oils. According to Slavica $R^{22}$ the difference between concentrations of element in the soil and plant could be explained by the fact that the root absorption mechanism is not able to absorb

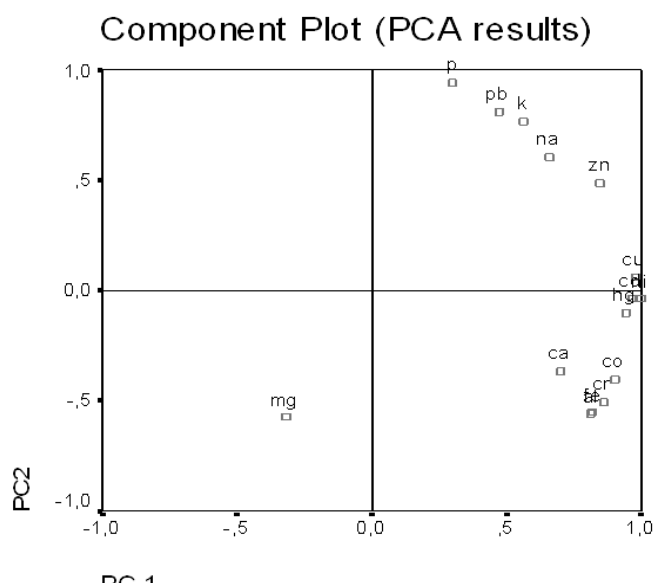

PC 1

Fig. 1: PCA biplot of correlation between mineral compounds all the element in their total amount. The results showed that the concentration of the low element varies considerably in the leaves and essential oil of the same plant.

Table 2 presents the correlation matrix of fifteen elements. The data set of concentration measurements was subjected to principal components and hierarchical cluster analysis in order to highlight the relations between the elements.

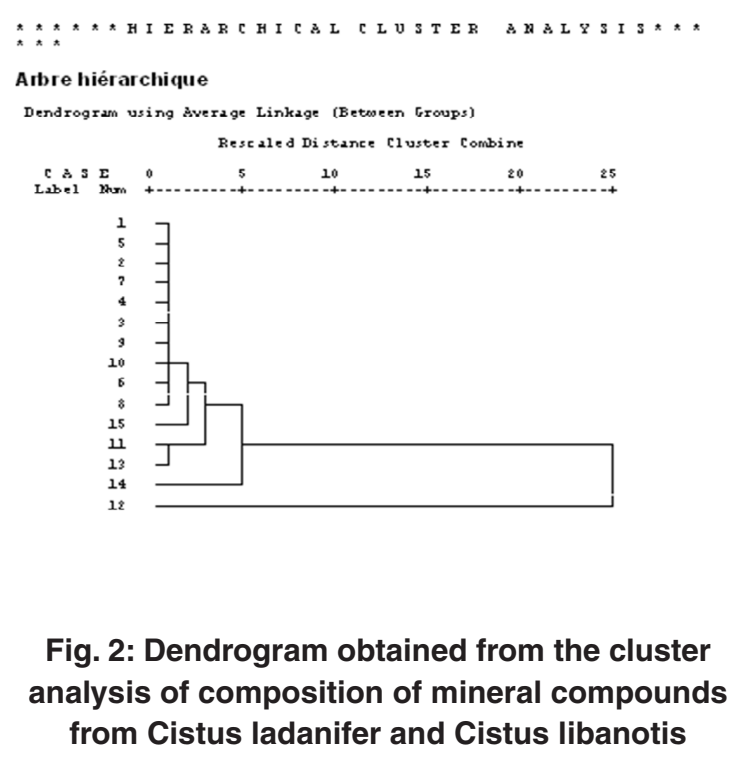


Principal component analysis (PCA) removes the highly inter-correlated nature of variations in trace element concentrations. Figure 1 illustrates principal component plot in tow dimensional space. It can be seen that tow principal components appeared to account for $83 \%$ of the variance in the data. The first principal component shows a high positive correlation with variables. The second principal component comprises $\mathrm{K}, \mathrm{Zn}, \mathrm{Pb}, \mathrm{P}$, $\mathrm{Na}$ and $\mathrm{Cu}$.

The proximity between samples was obtained by hierarchical cluster analysis. A dendrogram is shown in figure 2 . The cluster analysis suggested the existence of groups based minerals compounds. The first group was constituted by $\mathrm{Ca}$, and the second group by the other elements.

\section{CONCLUSIONS}

In the present work, the trace elemental analysis of two medicinal plants of their leaves, essential oils, and soil which they was grown, was analysed by ICP-AES and $\mathrm{Cd}, \mathrm{Co}, \mathrm{Cr}, \mathrm{Cu}, \mathrm{Hg}, \mathrm{Na}$, $\mathrm{Ni}, \mathrm{P}, \mathrm{Pb}, \mathrm{Zn}, \mathrm{Al}, \mathrm{Ca}, \mathrm{Fe}, \mathrm{K}$ and $\mathrm{Mg}$ were identified and their concentration were estimated.

These plants were found to contain appreciable amounts of the elements $\mathrm{K}, \mathrm{Ca}, \mathrm{Fe}, \mathrm{Mg}$, $\mathrm{P}, \mathrm{Al}, \mathrm{Ni}, \mathrm{Li}, \mathrm{Zn}$ and $\mathrm{Cu}$ Witch are importance in many biological mechanisms. Our results suggest that the analyzed medicinal plant Cistus ladanifer and Cistus libanotis can be considered as potential sources for diet if they are controlled.

\section{REFERENCES}

1. Attaguile, L.G., Russo, A., Campisi, A., Savoca, F., Acquaviva, R., Ragusa, N., Vanella, A. Antioxidant activity and protective effect on DNA cleavage of extracts from Cistus incanus L. and Cistus monspeliensis L. Cell. Biol. Toxicol., 16: 83-90 (2000).

2. Aziz, M., Karim, A., Tab, N., Mekhfi, H., Bnouham, M., Ziyyat, A., Legssyer, A., Atmani, F. Antidiarrhoeal activity of Cistus ladaniferus aqueous extract. Spatulla DD., 13: 175-179 (2011).

3. Belmokhtar, M., Bouanani, N., Ziyyat, A., Mekhfi, H., Bnouham, M., Aziz, M., Mateo, P., Fischmeister, R., Legssyer, A. Antihypertensive and endothelium-dependent vasodilator effects of aqueous extract of Cistus ladaniferus. Biochem. Biophys. Res. Commun., 389: 145-149 (2009).

4. Greche, H., Mrabet, N., Zrira, S., IsmailiAlaoui, M., Benjilali, B., Boukir, A. The volatiles of the leaf oil of Cistus ladanifer L. var. albiflorus and Labdanum extracts of Moroccan origin and their antimicrobial activities. J. Essent. Oil Res., 21: 166-173 (2009).

5. Amensour, M., Sendra, E., Pérez-Alvarez, J.A., Skali-Senhaji, N., Abrini, J., Fernández-
López, J. Antioxidant activity and chemical content of methanol and ethanol extracts from leaves of rockrose (Cistus ladaniferus). Plants Foods Hum. Nutr., 65: 170-178 (2010).

6. Mrabet, N., Lahlou, H., Benjilali, B. Effect of Moroccan Cistus ladaniferus L. (rockrose) extracts on the growth of four fungi. Cryptogamie Mycol., 20: 23-33 (1999).

7. Mekhfi, H., El Haouari, M., Legssyer, A., Bnouham, M., Aziz, M., Atmani, F., Remmal, A., Ziyyat, A. Platelet ant-aggregant property of some Moroccan medicinal plants. J. of Ethnopharma., 94: 317-322 (2004).

8. Aziz, M., Tab, N., Karim, A., Mekhfi, H., Bnouham, M., Ziyyat, A., Melhaoui, A., Legssyer, A. Relaxant effect of aqueous extract of Cistus ladaniferus on rodent intestinal contractions. Fitoterapia, 77: 425428 (2006).

9. Subba Rao, P.V., Vaibhav, A., Mantri, K. Ganesan Mineral composition of edible seaweed Porphyra vietnamensis. Food Chemistry, 102: 215-218 (2007).

10. Kulkarni, S.D., Acharya, R., Nair, A.G.C., Rajurkar, N.S., Reddy, A.V.R. Determination of elemental concentration profiles in tender wheatgrass (triticum aestivum L.) using 
instrumental neutron activation analysis. Food Chemistry, 95: 699-707 (2006).

11. Abugassa, I.O., Bashir, A.T., Doubali, K., Etwir, R.H., Abu-Enawel, M., Abugassa, S.O. Characterization of trace elements in medicinal herbs by instrumental neutron activation analysis. Journal of Radioanalytical and Nuclear Chemistry, 278: 559-563 (2008).

12. Ayenimo, J.G., Yusuf, A.M., Adekunle, A.S., Makinde, O.W. Heavy Metal Exposure from Personal Care Products. Bull. Environ. Contam. Toxicol., 84: 8-14 (2010).

13. WHO, World Health Organization Environmental Health Criteria: International Programme on Chemical Safety, Geneva, 165 (1995).

14. Özcan, M. Mineral contents of some plants used as condiments in Turkey. Food Chemistry, 84: 437-440 (2004).

15. Sayyed, M.R.G., Sayadi, M.H. Variations in the heavy metal accumulations within the surface soils from the Chitgar industrial area of Tehran. Proceedings of the Inter. Acad. of
Ecol. and Envir. Sc. 1(1): 36-46 (2011).

16. Chan, K. Some aspects of toxic contaminants in herbal medicines. Chemosphere, 52: 13611371 (2003).

17. Maiga, A., Diallo, D., Bye, R., Paulsen, B.S. Determination of some toxic and essential metal ions in medicinal and edible plants from Mali. Journal of Agricul. and Food Chem., 53: 2316-2321 (2005).

18. Meagher, R.B. Phytoremediation of toxic elemental and organic pollutants. Curr. Opin. Plant Biol., 3(2):153-162 (2000).

19. Steflitsch, W., Steflitsch, M. Clinical aromatherapy. Jmh., 5: 74-85 (2008).

20. M. Hussain, T.V.D.P. Rao, H.A. Khan and M. Satyannarayanan, Orient J. Chem., 27(4): 1679-1684 (2011).

21. Brody, T. Nutritional biochemistry. San Diego, CA: Academic press (1994).

22. Slavica, R., Antonije, O., Branislav, P. Trace elements analysis of Echinacea purpurea herbal medicinal. Journal of Pharm. and Biomed. Analysis., 33: 845-850 (2003). 